\title{
Fiscal transfer system of the three proposed federal form of government in the Philippines: A Case of Northern Mindanao
}

\author{
Marivic L. Seno ${ }^{a}$, Renato L. Base ${ }^{b}$ \\ a marivic.seno@gmail.com, University of Science and Technology of Southern Philippines, Cagayan de Oro City, Philippines \\ ${ }^{\mathrm{b}}$ renato.base@ ustp.edu.ph, University of Science and Technology of Southern Philippines, Cagayan de Oro City, Philippines
}

\begin{abstract}
This study aspires to shed light on the proposed shift to a federal system of government in the Philippines if it will indeed foster further development to the local government units (LGUs) to be independent and self-reliant communities. The three federalism proposals were compared in the aspect of fiscal transfer from the National Government to the Local Government Units namely, the Concom proposal, Pimentel proposal, and the CMFP proposal. The fiscal transfer design of these three proposals were tested and compared as to its viability and how it will impact the income generation of the LGUs.

This study used cluster sampling method wherein the population of the Local Government Units within the State of Northern Mindanao was clustered by LGU level namely, provinces, cities, and municipalities. This study used quantitative data analysis based on the archival data and qualitative data to further reinforce the quantitative findings.

The result of the study showed that the Pimentel proposal would significantly increase the income of the LGUs that would be translated to higher spending capabilities to support the delivery of basic services to its constituents. However, it would also mean an increase in the dependence of the LGUs from national support. Moreover, Local Chief Executives expressed their doubts as to the necessity to shift to a federal form of government due to identified factors.
\end{abstract}

Keywords: fiscal transfer; fiscal decentralization, federal form of government; local government units, local autonomy

\section{Introduction}

The Local Government Code (LGC) known also as Republic Act No. 7160: An Act Providing for a Local Government Code of 1991 instituted the principles of fiscal decentralization in the Philippines (Manasan, Philippine Journal of Development, 2005). The Local Government Code provides power to the local government units to be able to operate on their own and be able to achieve their full potential as self-sustaining communities (Republic Act No. 7160, 1991).

Along with the decentralization, as mandated in the Local Government Code, primary responsibilities of the national government were transferred to the local government units to deliver basic services and operations of facilities. However, the decentralization had resulted in an increase in spending by the LGUs. On this, Manasan (2005) noted that the share of the LGUs in government spending had doubled from $12.6 \%$ in 1991 (before devolution) to 25.4\% in 2003. Moreover, from Year 2014 to 2016, the average LGUs spending 
was $18 \%$ of the total government expenditure wherein national government expenditures were recorded at the average of PHP 2,253.87 Billion (Bureau of the Treasury, 2018) while the LGU expenditures were recorded at the average of PHP 405.68 Billion (Bureau of Local Government Finance, 2017).

Consistent with the principle of fiscal decentralization, the Local Government Code granted authority to the local government units to create their sources of revenue and to collect taxes, fees, and charges, which must be underpinned by appropriate ordinance (Republic Act No. 7160, 1991). Despite this power and authority, the taxing power of LGUs was limited and should not extend to the taxes, fees, and charges covered by the national government as enumerated in Sec. 133 of the Local Government Code. Furthermore, the Local Government Code also sets the limit as to the local tax rates that LGUs can impose. Thus, it is reasonable to say that fiscal autonomy was not completely granted to the LGUs.

Because of this imposed limitation inherent in the Local Government Code, the locally-sourced income of the LGUs was negatively affected. To prove this, from 2012 to 2016 only $30 \%$ on average of the total revenue of the LGUs (Bureau of Local Government Finance, 2017) were locally sourced while $70 \%$ of LGUs income came from the national government through the Internal Revenue Allotment.

The Internal Revenue Allotment (IRA) was crafted in the form of Executive Order (EO) No. 507 in support of LGUs expenditures in general services and social services. This Executive Order enumerated the devolution-affected departments and agencies of the national government whose appropriations shall be transferred to the local government units through the Internal Revenue Allotment. However, the IRA system is criticized due to its shortcomings in addressing the expenditure needs of the LGUs (Manasan, Policy Notes, 2007).

Through the years of its implementation, its weakness in addressing LGUs' fiscal imbalance became more evident. By strengthening the revenue-raising capabilities of the LGUs, the issue of fiscal imbalance might be addressed. Manasan (2007) recommended greater tax decentralization and more tax bases to the LGUs so that accountability will improve at the local level.

Given the impending federalization of our government, it opens up an opportunity in which the aforesaid fiscal imbalance can be possibly addressed. This is in the form of fiscal transfer systems that can be gleaned from three (3) federalism proposals that were supposed to strengthen the revenue-raising capabilities of LGUs. The first proposal that was considered in this study was the recently released Draft Constitution crafted by the Consultative Committee (Concom) to Review the 1987 Constitution headed by Retired Chief Justice Renato Puno entitled "Power to the People: Bayanihan Federalism, Power to the Regions" (Consultative Committee to Review the 1987 Constitution, 2018)

The second proposal was Joint Resolution No. 10 introduced by Sen. Aquilino Pimentel, Jr. entitled "Joint Resolution to Convene the Congress into a Constituent Assembly to revise the Constitution to Establish a Federal System of Government" filed on April 23, 2008 (Pimentel, et al., 2008). And, the third proposal that was considered was the Citizen's Movement for a Federal Philippines (CMFP) entitled "CMFP Draft Constitution for the Federal Republic of the Philippines with a Parliamentary Government" with Prof. Jose V. Abueva as the Chairman of the Advisory Committee (Citizens' Movement for a Federal Philippines (CMFP), 2005).

Given the first proposal, the Consultative Committee proposed combining both the reallocation of the expanded tax base to the States coupled with fiscal sharing scheme. In its proposed fiscal sharing scheme, the Federated Regions will "be given a share of not less than fifty percent (50\%) of all the collected income taxes, 
excise taxes, value-added tax, and customs duties, which shall be equally divided among them and automatically released" (Consultative Committee to Review the 1987 Constitution, 2018).

On the other hand, the Pimentel Proposal provides a sharing scheme of taxes between the national government, the state governments, and the LGUs. Article XII of the Joint Resolution No. 10 stated that the fiscal transfer system provides a sharing of taxes between the National Government and the local government units, as stated in the Local Government Code of 1991, shall be revised. The revision could mean that "all revenues and taxes collected by the local government units or by national government agencies under the Local Government Code of 1991, Republic Act No. 7160, shall be divided in the following manner: twenty percent (20\%) shall accrue to the Federal Government and eighty percent $(80 \%)$ to the States where $30 \%$ shall pertain to the States concerned while the $70 \%$ shall be distributed to the constituent LGUs according to the existing formula in the Local Government Code" (Pimentel, et al., 2008).

There is a need to emphasize though that a critical consideration in Pimentel's fiscal transfer system is the political configuration of the local government. In the current unitary system, the local government is composed of provinces, cities, municipalities, and barangays. However, in the political configuration, as envisioned by the proposal of Sen. Pimentel, the State Government will be added in between the Federal Government and the Local Government (Pimentel, et al., 2008). Therefore, this proposal consisted of the same layers (three layers) of the local governance structure as mandated by the Local Government Code. That is, under the State Government, the first layer of local governance is the province and independent cities. The second layer is the municipalities and component cities. The last layer is the barangay, the smallest political unit (Manasan, Philippine Journal of Development, 2005). On the other hand, the CMFP Draft Constitution stated that the province will be considered only as an administrative subdivision. Hence, this proposal, it will do away with the province as a structure of local governance. As a result, it will only consist of two (2) layers of local governance (Abueva, 2005). Meanwhile, the Consultative Committee's proposal is silent as to the political configuration of the local government units.

Given this, under the current unitary form of government, as stated in Section 285 of the Local Government Code of 1991, $40 \%$ of the national income is distributed to the LGUs in the form of IRA in which $23 \%$ goes to the provinces, $23 \%$ to cities, $34 \%$ to municipalities, and $20 \%$ to barangays. Furthermore, in the proposal forwarded by Sen. Pimentel, its fiscal sharing system uses the 80-20 tax-sharing scheme in which the tax share of the LGUs is computed based on the proposed LGU political structure that consisted of three (3) layers of local governance. While in the CMFP scheme, its fiscal sharing system was not defined but instead, it proposes a reallocation of an expanded tax base to the State. This expanded tax base is within the ambit of its proposed two (2) layers of local government structure instead of three (3).

There is a need to emphasize that the number of States to be created will have ramifications to the fiscal transfer systems being proposed inherent in the three proposals mentioned above. For instance, the Pimentel proposal pushed for the creation of eleven (11) States in addition to the Federal Administrative Region which is Metro Manila while the CMFP proposed to create ten (10) States. The territory of the States was determined by the geographical location, ethnicity, language, and culture (Citizens' Movement for a Federal Philippines (CMFP), 2005). On the other hand, Article XI Section 1 of the Draft Constitution of the Consultative Committee proposed for sixteen (16) Federated Regions, the Bangsamoro, and the Federated Region of the Cordilleras (Consultative Committee to Review the 1987 Constitution, 2018).

Furthermore, the CMFP proposal envisioned that the taxes that are collected by the national government, are to be reallocated to the State governments so that the States and the local governments will be able to exercise their functions and deliver basic services to their constituents. Major tax bases such as income 
tax, value-added tax, documentary stamp tax, and other percentage taxes shall be allocated to the States as well as taxes under special laws such as motor vehicle tax and travel tax (Abueva, 2005). Under Article XII Section 1 to 4 of Consultative Committee Draft Constitution, on the other hand, also identified some taxes that the Federated Regions can levy and collect however it does not include the major taxes such as income taxes, excise taxes, and value-added tax. These major taxes including the customs duties shall still be under the central government, but the Federated Regions will have a share of not less than $50 \%$ of the collection of these taxes and customs duties which shall be equally divided among the States or Federated Regions (Consultative Committee to Review the 1987 Constitution, 2018). Under the CMFP and Concom proposals, the actual allocation of the tax collections of the States to their corresponding local government units is not defined. For this reason, the horizontal and vertical fiscal transfer system specified in the Local Government Code will be applicable.

Because of this, the three proposals have shown the gaps, which need to be filled - in the current fiscal transfer system under the Local Government Code. In response, the study therefore will attempt to fill in the said gap by subjecting to analysis the inherent fiscal transfer system embedded in each of these proposals in the context of an impending federalization of the Philippines.

\subsection{Problem Statement}

With the above serving as the backdrop, this put into the limelight the proposals mentioned above, namely: the Pimentel proposal, the CMFP proposal, and the Cocom proposal. Thus, the study would attempt to determine from these three proposals, which one has a viable fiscal transfer system as far as the LGUs are concerned; second, which of the three proposals can strengthen the revenue-raising capabilities of LGUs.

In line with this, the primary objective of the study is to find out which of the three proposals can significantly increase the revenue share of the LGUs; hence, addressing the fiscal imbalance, and whether such increase has practical significance to support LGU expenditures in the area of general services and social services; thus, addressing which of the proposals is effective towards strengthening revenue-raising capabilities of LGUs.

With this end in mind, the study seeks to answer the following queries, namely:

- How much is the actual internal revenue allotment received by the LGUs in the three regions namely; Northern Mindanao, Zamboanga Peninsula, and Caraga Region in the fiscal years 2014 to 2018 ?

- Excluding the locally sourced income, how much is the projected aggregate amount of fiscal transfer to be received by the LGUs in the State of Northern Mindanao under the three (3) federalism proposals in the fiscal year 2014 to 2018 ?

- How much is the total projected income of LGUs under each federal proposal including the locally sourced income in the fiscal year 2014 to 2018 ?

- How much is the distribution of the LGU Income by service sector under the three federal proposals as to general public services, social services, economic services, and debt service?

- Which of the three proposals has practical significance for the Local Chief Executives?

- Overall, based on the findings of the above queries and from the point of view of the local chief executives, which of the three proposals can address the fiscal imbalance, as well as strengthen the revenue-raising capabilities of LGUs? 
1.2. Conceptual Framework

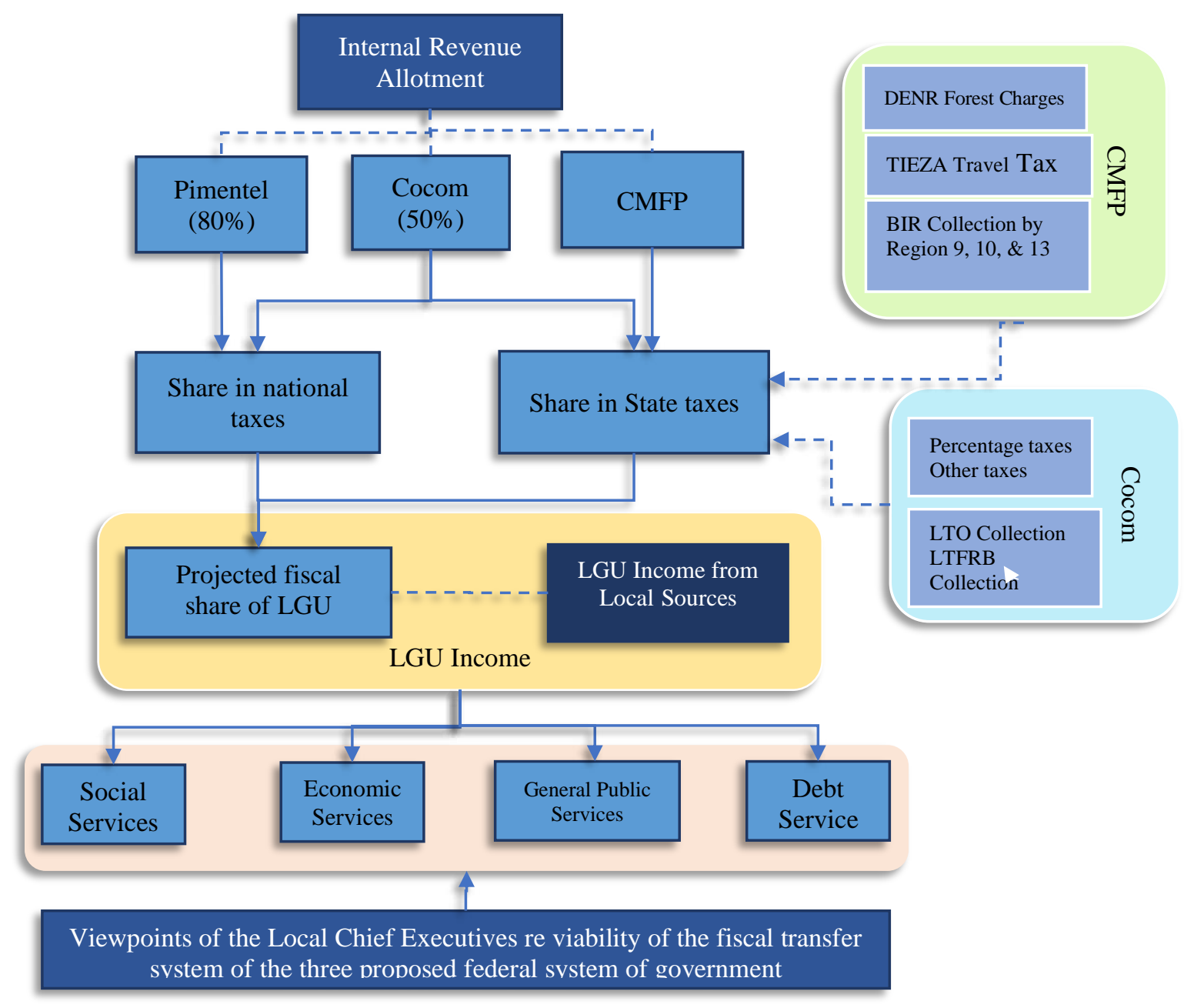

Figure 1. The Conceptual Framework of the Study

The study is anchored on the notion of intergovernmental fiscal transfer. The main objective of intergovernmental fiscal transfer (Shah, et al., 2006) is to fund the fiscal imbalance between expenditure needs and the revenue-raising responsibilities of the local government brought about by decentralization. "Transfers may refer to several different kinds of public financing instruments such as grants, shared taxes, subsidies, and subventions" (Bahl, 2000). The three proposals of a federal system of government have different mechanisms in which intergovernmental fiscal transfer is to be carried out. If ever one of these proposals will become the basis in the crafting of the proposed federal system of government, then, their proposed mechanism in the fiscal transfer system will be followed. 
As shown in the above conceptual scheme, this study presents the actual internal revenue allotment (IRA) received by the LGUs based on historical data.

There are three federalism proposals namely, Cocom, Pimentel, and CMFP that were considered in this study wherein the respective fiscal transfer system was analyzed.

The broken arrow from IRA going down to the three (3) federalism proposals represents the indirect relationship wherein the projected fiscal transfer of the three (3) political configurations will be compared to the actual IRA that the LGUs received from the national government.

Under the Pimentel proposal, the arrow going down to the Share in National Taxes represents the projected share of the LGUs in the $80 \%$ share in the national taxes.

Under Concom, on the other hand, the arrow going to the Share in the National Taxes represents the 50\% share in the national taxes such as income tax, value-added tax, and customs duties. Another arrow pointing down to the Share in State Taxes represents the share of the LGUs that will be received from the State tax collection. The State Taxes are coming from the proposed transfer of the taxing power to the State such as percentage taxes and other taxes (these are collected by BIR) well taxes and fees under special laws such as [road users tax, vehicle registration fees (collected by Land Transportation Office)], transport franchise fees (collected by Land Transportation Franchising and Regulatory Board), and local taxes and other local taxes which may be granted by federal law.

Furthermore, the arrow from CMFP to the Share in the State Taxes represents the share of the LGUs from the collection of State taxes. CMFP proposed to transfer the taxing power to the States for national taxes such as [income taxes on individuals and corporations as well as value-added tax, other percentages taxes such as franchise tax, taxes on banks and non-bank financial intermediaries, tax on finance companies, and tax on gross receipts of life insurance companies, documentary stamp tax(collected by the Bureau of Internal Revenue)], and taxes and fees under special laws such as [motor vehicle registration fees, private motor vehicle tax (Land Transportation Office)], travel tax (collected by Tourism Infrastructure and Enterprise Zone Authority), and charges on forest products (collected by the Department of Environment and Natural Resources).

The share in the national taxes combined with the share in the state taxes become the projected fiscal share of the LGUs. On the other hand, the projected fiscal share of the LGUs combined with the actual LGU local tax collections, which are based on historical data, will be considered as LGU's Income. This LGU Income will be used to finance the expenditures of the LGU, categorized in terms of social services, economic services, general public services, and debt services. From this, the viability of the proposed fiscal transfers and the effect of the three proposals on LGU income were used as the basis wherein viewpoints of local chief executives were elicited.

\subsection{Significance of the study}

This study is significant to the following:

- $\quad$ Federalism proponents as a reference to further study on the effect in the total revenue of the local government units if the federal system of government shall be adopted. 
- Lawmakers as a reference to craft an effective fiscal policy that is more beneficial for LGUs and the local communities.

- Local government officials and administrators and the local communities as direct beneficiaries of further economic development.

\subsection{Scope and limitations of the study}

The study focused on the comparative analysis of the tax-sharing scheme as envisaged in the proposal of Sen. Pimentel, and the CMFP proposal, and the draft constitution by the Consultative Committee. Thus, the scope of the analysis included the following:

1. The tax-sharing scheme as stated in Joint Resolution No. 10 under the federal system, the CMFP Draft Constitution, and the ConCom Draft Constitution.

2. Under the three federalism proposals, the comparison will only be limited to their respective proposed local government political configuration, tax-sharing scheme, and tax reallocation scheme.

The study used the data of the Internal Revenue Allotment (IRA) in the Calendar Years 2014, 2015, 2016, 2017, and 2018 from the Bureau of the Treasury and the Department of Budget and Management. The total IRA figures taken from the Local Budget Memorandums of the Department of Budget and Management was assumed as $40 \%$ of the national taxes, net of allowable deductions covered by special laws.

The sample LGUs was drawn from the cluster of LGUs; hence, the sample was taken as being representative of the population of LGUs from which it came from. Nevertheless, for this study, cities were classified as the same regardless of their being a highly urbanized city or a component city.

The barangays were not included in the study.

To present the comparison, the following parameters were set for the sample data used in the comparative analysis:

- It only included the national internal revenue taxes collected by BIR in the calendar years 2011, 2012, 2013, 2014, and 2015 used as the basis for the IRA computation in calendar years 2014, 2015, 2016, 2017, and 2018. The tax collections from taxpayers classified by BIR as Large Taxpayers were not included under BIR Revenue Region No. 16 (even such taxpayers are located within Northern Mindanao) since tax payments from Large Taxpayers are centralized and directly remitted to the Large Taxpayer Service (LTS) Division of the BIR.

- The cost of the devolved function was not considered in the computation of the proposed tax sharing for the federal government structure.

- $\quad$ Local taxes collected by the LGUs was only considered in the computation of the LGU income.

- Special share of LGUs in the proceeds of national taxes from the gross collection derived from excise taxes on mineral products, royalties, and such other taxes fees or charges was considered only in the computation of the LGU income as part of the income from other sources.

- $\quad$ Fiscal equalization and equalization fund were not included in this study.

- The court decision on the petition of Congressman Hermilando Mandanas later known as "Mandanas ruling" was not included in this study (Congressman Hermilando I. Mandanas, et al. Vs. Executive Secretary Paquito N. Ochoa, Jr., et al./Honorable Enrique T. Garcia, Jr. Vs. Honorable Paquito N. Ochoa, Jr., et al., 2019). 
The Key Informant Interview was only limited to the Local Chief Executive of the One Municipality and one Highly-Urbanized City because it was not possible to conduct more face-to-face interviews with the local chief executives due to observance of health protocols and travel restrictions imposed by the Health authorities and LGUs during the Covid19 pandemic situation.

\subsection{Methodology}

The research was conducted in the State of Northern Mindanao, which is the locus of this study.

Under Pimentel's proposal, the State of Northern Mindanao shall comprise of the eleven (11) provinces namely: Zamboanga del Norte, Misamis Occidental, Camiguin, Misamis Oriental, Bukidnon, Agusan de Norte, Dinagat Island, Surigao de Norte, Lanao del Norte, Zamboanga del Sur and Zamboanga Sibugay. All cities and municipalities within these provinces shall also be included under the State of Northern Mindanao (Pimentel, Federalizing the Philippines: A Primer, 2008).

On the other hand, the CMFP proposed that the Zamboanga Peninsula and the Northern Mindanao shall be consolidated into the State of Western and Northern Mindanao which shall be comprised of twelve (12) provinces, namely: Zamboanga del Norte, Zamboanga de Sur, Zamboanga Sibugay, Bukidnon, Camiguin, Misamis Occidental, Misamis Oriental, Agusan del Norte, Agusan del Sur, Surigao del Norte, Surigao del Sur, and Dinagat Islands* (Abueva, 2005).

Furthermore, the Consultative Committee proposed that there shall be eighteen (18) federated regions. Out of the eighteen (18) regions, one region is the Federated Region of Northern Mindanao that will comprise of the provinces of the current Region X, namely, Bukidnon, Camiguin, Lanao del Norte, Misamis Occidental, and Misamis Oriental (Consultative Committee to Review the 1987 Constitution, 2018).

Based on the above considerations, the significance of the State of Northern Mindanao has been highlighted therefore this served as the basis in its choice as the locale in which this study was conducted.

This study used cluster sampling method wherein the population of the Local Government Units within the State of Northern Mindanao shall be clustered by LGU level namely; provinces, cities, and municipalities.

The samples were drawn from the cluster of provinces. Correspondingly, sample municipalities will be drawn out of the cluster of municipalities under the sample provinces. Samples will also be drawn from the cluster of cities.

This sampling method was applied for each data set of the three federalism proposals.

This study used quantitative data analysis based on the archival data of the internal revenue allotment (IRA) that will be taken from the Bureau of Treasury and the Department of Budget and Management that covers the

\footnotetext{
* Dinagat Islands (as added by the authors) was once under Surigao del Norte but was created as a province through RA 9355 on July 24, 2006 (Republic Act No. 9355, 2006)
} 
Calendar Years 2014 to 2018 as well as the revenue collections of the identified revenue collection agencies covering the period Fiscal Year 2014 to 2018. However, the analysis and findings that will result from this will then be supplemented by the findings of the Key Informant Interview (KII) of key LGU officials from the governor down to the municipal mayor. These findings will then be woven together in the discussion to come up with insight, which of the three proposals can significantly increase the revenue share of the LGUs in the areas of general services and social services, and which one can strengthen the revenue collection of the LGUs in the context of a federalized form of government.

In doing the computation, it was anchored on the supposition that the IRA is computed as $40 \%$ of the national internal revenue taxes collected by the Bureau of Internal Revenue on the third fiscal year that precede the year the actual IRA is released to LGUs.

The said computation will take its cue from archival data such as:

- The Local Budget Memorandums issued by the Department of Budget and Management for the internal revenue allotment in FY 2014, 2015, 2016, 2017, and 2018 were used as the basis to determine the total national taxes in the Calendar Year 2011 to 2015 (Department of Budget and Mangement, 2014 - 2018).

- The amount of IRA released to the LGUs under Region IX, X, and XIII from the Bureau of the Treasury and the Department of Budget and Management covering the FY 2014 to 2018.

- The Bureau of Customs collections were based on the annual report of the Bureau of the Treasury (Bureau of the Treasury, 2018).

- $\quad$ Bureau of Internal Revenue collections for FY 2014 to 2018 (Bureau of Internal Revenue, 2014 - 2018)

- The other Bureau of Internal Revenue (BIR) collections for the ConCom proposal were based on the report of BIR Revenue Region No. 16 covering the Northern Mindanao Region based on the Economic Updates from the National Economic and Development Authority (NEDA) Region X for FY 2014 to 2018 (National Economic Development Authority - Region X, 2014 - 2018).

- Land Transportation Office (LTO) Collections under LTO Region IX, X, XIII based on the LTO annual report for FY 2014 to 2018 (Land Transportation Office, 2014 - 2018)

- Land Transportation Franchising and Regulatory Board (LTFRB) Collections by LTFRB Region10 for FY 2014 to 2018 (only under ConCom proposal)

- $\quad$ Forest charges under Region IX, X, XIII based on the Philippine Forestry Statistics for 2014 to 2018 (Forest Management Bureau, 2014 - 2018)

- Travel tax collection under Region IX, X, and XIII collected by the Tourism Instructure and Enterprise Zone Authority (TIEZA) for FY 2014 to 2018 (Tourism Infrastucture and Enterprise Zone Authority, 2014 - 2018)

To gather qualitative data that will further reinforce the quantitative findings, a Key Informant Interview (KII) was conducted with the Local Chief Executives (LCE) from each cluster of LGUs to discuss the result of the statistical data analysis and to know the viability of the result of the data.

\section{Results and Findings}

In the current scenario, the LGUs receive a share in national taxes through the internal revenue allotment (IRA). Internal revenue allotment is equivalent to the $40 \%$ of the internal taxes collected in the third fiscal year 
preceding the current fiscal year. The internal revenue allotment is allocated to the LGUs in a manner as prescribed by the Local Government Code as $23 \%$ for provinces, $23 \%$ for cities, $34 \%$ for municipalities while the remaining $20 \%$ goes to the barangays. Furthermore, the share of each province, city, and municipality is based on Sec. $285 \mathrm{~d}$ of the Local Government Code which is; $50 \%$ based on population, $25 \%$ based on land area, and $25 \%$ based on equal sharing.

The design of the fiscal transfer of the three federalism proposals namely; ConCom Proposal, Pimentel Proposal, and the CMFP Proposal were analyzed and interpreted using the archival data from the following government agencies: Department of Budget and Management, Bureau of Internal Revenue, Land Transportation Office, Bureau of the Treasury, National Economic and Development Authority-Regional Office X, Department of Environment and Natural Resources, Tourism Infrastructure and Enterprise Zone Authority (TIEZA), and the Electronic Freedom of Information (e-FOI).

The fiscal share to be received by the State will be distributed as follows; $70 \%$ to LGUs and $30 \%$ retained by the State (Joint Resolution No. 10, 2008). Accordingly, the $70 \%$ for the LGUs will be shared among the provinces, cities, municipalities and barangays. Applying the same sharing scheme as prescribe in Section 285 of the Local Government Code to determine the estimated amount of fiscal transfer to the LGUs under the three federalism proposals, the tax bases as specified in each proposal were considered. Nonetheless, the political configuration of each proposal was also factored in.

As proposed by ConCom, the Federal Republic of the Philippines will be divided into eighteen (18) Federated Regions. The Region X will be converted in Northern Mindanao Federated Region composed of five (5) provinces including its nine (9) cities and eighty-four (84) municipalities within its territorial jurisdiction (Consultative Committee to Review the 1987 Constitution, 2018).

Under the Concom proposal, the local government units in the Northern Mindanao Federated Region will received the fiscal share from the national taxes and state taxes.

On the other hand, the State of Northern Mindanao under the Pimentel proposal will cover eleven (11) provinces of the Region X-Northern Mindanao, Region IX- Zamboanga Peninsula, and Region XIII-Caraga Region excluding the provinces of Agusan del Sur and Surigao del Sur. These provinces will be included under the State of Southern Mindanao which is not included in this study. Furthermore, the sixteen (16) cities and one hundred eighty-eight (188) municipalities within its territorial jurisdiction of the eleven (11) provinces will also be included.

With regards to the CMFP proposal, the State of Northern Mindanao will include the current Region IXZamboanga Peninsula, Region X-Northern Mindanao, and Region XIII -Caraga Region. It will be composed of the provinces of Agusan del Norte, Agusan del Sur, Surigao del Norte, Surigao del Sur, Dinagat Islands which are currently under Region XIII (Caraga Region). The four (4) provinces of Region X are also included namely Bukidnon, Camiguin, Misamis Oriental, and Misamis Occidental. Lanao del Norte is excluded as it will be under the State of Central and Southern Mindanao. Furthermore, the provinces of Zamboanga del Norte, Zamboanga del Sur, and Zamboanga Sibugay are also part of the State of Northern Mindanao under CMFP proposal. It is also noted that CMFP proposed that the provincial government will be abolished. It is noted that the provinces will no longer be a political subdivision of the State but rather will be considered only as administrative subdivision (Citizens' Movement for a Federal Philippines (CMFP), 2005). 


\subsection{Fiscal Share versus Internal Revenue Allotment}

In the following tables below, the share of LGUs in the IRA is being compared with the share in the fiscal transfer to be received by the LGUs in the State of Northern Mindanao. The difference in amount is presented as well as the percentage difference.

Table 1. Comparison of the Internal Revenue Allotment vs Fiscal Transfer to LGUs in the Northern Mindanao Federation Region under ConCom Proposal for FY 2014 to FY 2018

In Million Pesos

\begin{tabular}{lccccc}
\hline & FY 2014 & FY 2015 & FY 2016 & FY 2017 & FY 2018 \\
\hline Fiscal Share & 17,964 & 20,206 & 22,728 & 25,576 & 27,358 \\
IRA & 15,264 & 17,415 & 19,117 & 21,676 & 23,264 \\
\hline Difference & 2,699 & 2,792 & 3,611 & 3,900 & 4,094 \\
& & & & & $\mathbf{1 8 \%}$ \\
\hline Percentage & $\mathbf{1 8 \%}$ & $\mathbf{1 6 \%}$ & $\mathbf{1 9 \%}$ & $\mathbf{1 8 \%}$ \\
\hline
\end{tabular}

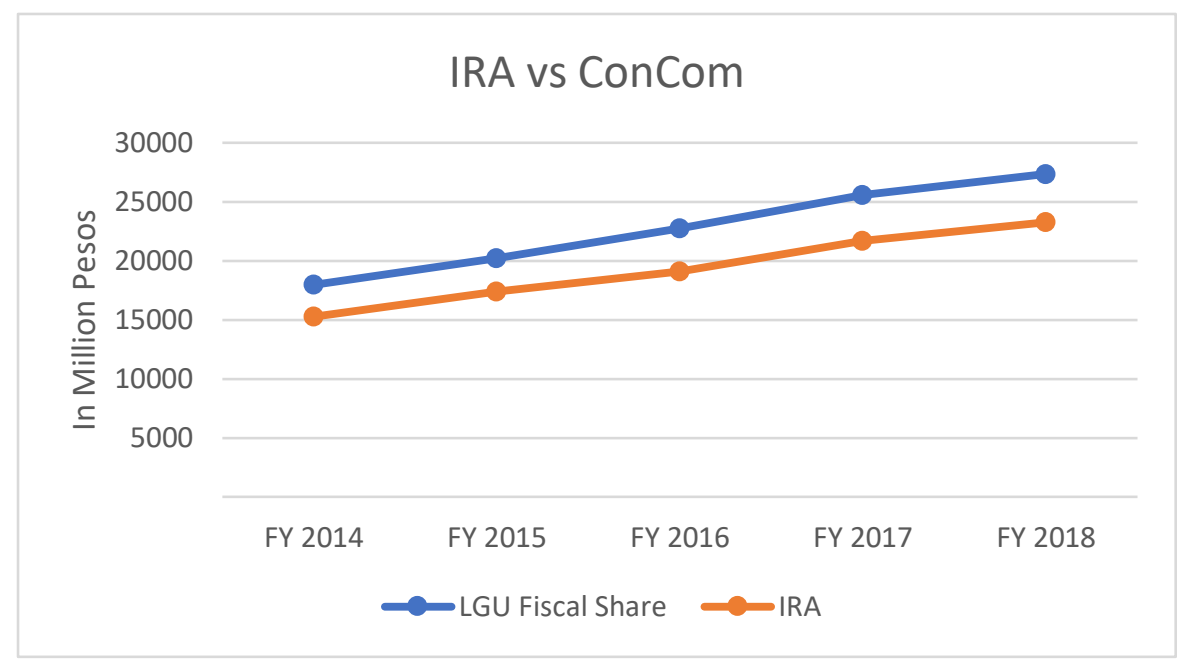

Figure 2. Graphical Representation of the Difference in the Internal Revenue Allotment and Fiscal Transfer to LGUs in the Northern Mindanao Federated Region in FY 2014 to FY 2018 under ConCom Proposal

As shown in Table 1, the difference in the internal revenue allotment and the fiscal transfer to the LGUs in the Northern Mindanao Federated Region under ConCom proposal is PHP 2,699 Million in FY 2014, PHP 2,792 Million in FY 2015, PHP 3,611 Million in FY 2016, PHP 3,900 Million in FY 2017, and PHP 4,094 Million in FY 2018. 
There was an increase in FY 2014 of 18\%, 16\% in FY 2015, $19 \%$ in FY 2016, $18 \%$ in FY 2017, and remain steady at $18 \%$ in FY 2018 respectively.

Figure 2 showed that there is a small gap between the IRA received by the LGUs vis-à-vis the income of the LGUs under the Concom proposal.

Table 2. Comparison of the Internal Revenue Allotment vs Fiscal Transfer to LGUs in the State of Northern Mindanao under Pimental Proposal for FY 2014 to FY 2018

\begin{tabular}{llllll}
\multicolumn{1}{c}{ In Million Pesos } & \multicolumn{7}{c}{} & & \\
\hline & FY 2014 & FY 2015 & FY 2016 & FY 2017 & FY 2018 \\
\hline Fiscal Share & 59,118 & 66,723 & 72,305 & 83,337 & 87,932 \\
IRA & 31,567 & 36,006 & 39,524 & 44,595 & 47,859 \\
\hline Difference & 27,551 & 30,717 & 32,780 & 38,741 & 40,073 \\
\hline Percentage & $\mathbf{8 7 \%}$ & $\mathbf{8 5 \%}$ & $\mathbf{8 3 \%}$ & $\mathbf{8 7 \%}$ & $\mathbf{8 4 \%}$ \\
\hline
\end{tabular}

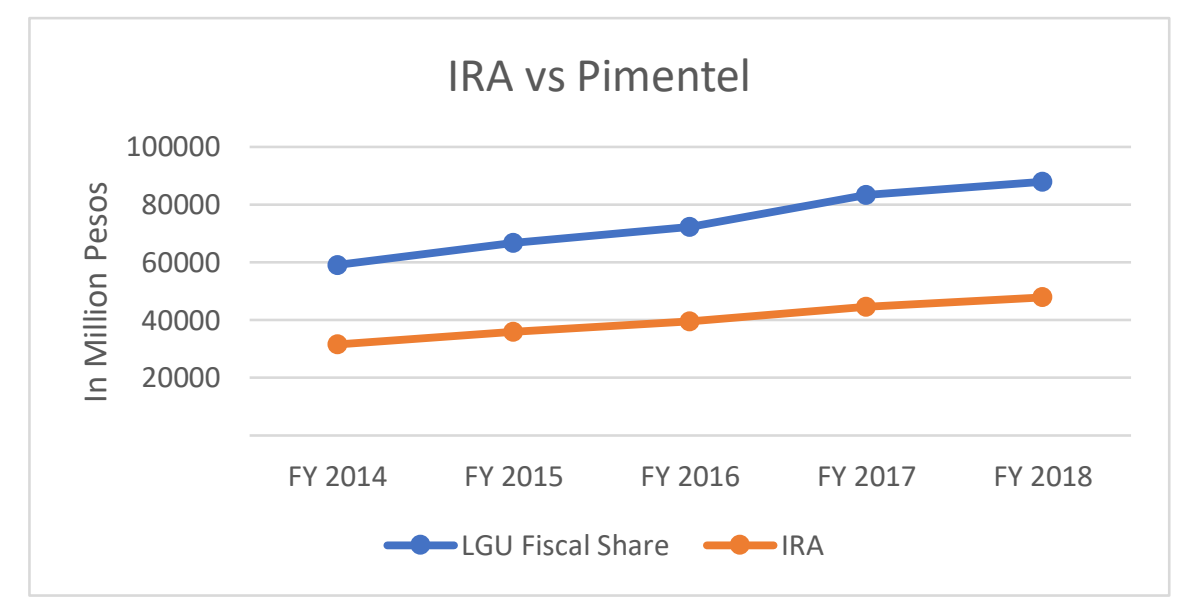

Figure 3. Graphical Representation of the Difference in the Internal Revenue Allotment and Fiscal Transfer to LGUs in the State of Northern Mindanao under Pimentel Proposal for FY 2014 to FY 2018

As shown in Table 2, the increase in the fiscal transfer to the LGUs in the Pimentel proposal vis-a-vis the internal revenue allotment is $87 \%$ in FY 2014 which is translated to PHP 27,551 Million, at 85\% in FY 2015 translated to PHP 30,717 Million, at 83\% in FY 2016 which is translated to PHP 32,780 Million, at 87\% in FY 2017 which would be equivalent to PHP 38,741 Million, and lastly 84\% in FY 2018 which is translated to PHP 40,073 Million. 
As illustrated in Figure 3, there is a huge gap from the IRA to the fiscal transfer proposed by Pimentel due to the higher share that the LGUs will receive. It is to be noted that Pimentel proposed that $80 \%$ of the national taxes shall be allocated to the State and that $70 \%$ of which shall be divided by the LGUs concerned in the same manner as prescribed in the Local Government Code.

Table 3. Comparison of the Internal Revenue Allotment vs Fiscal Transfer to LGUs in the State of Northern Mindanao under CMFP Proposal for FY 2014 to FY 2018

In Million Pesos

\begin{tabular}{llllll}
\hline & FY 2014 & FY 2015 & FY 2016 & FY 2017 & FY 2018 \\
\hline Fiscal Share & 8,907 & 9,810 & 11,619 & 3,559 & 37,374 \\
IRA & 24,596 & 28,075 & 30,844 & -816 & $-27,812$ \\
\hline Difference & $-15,689$ & $-18,265$ & $-19,225$ & $-22,258$ & $\mathbf{- 7 4 \%}$ \\
\hline Percentage & $\mathbf{- 6 4 \%}$ & $\mathbf{- 6 5 \%}$ & $\mathbf{- 6 2 \%}$ & $\mathbf{- 6 4 \%}$ & \\
\hline
\end{tabular}

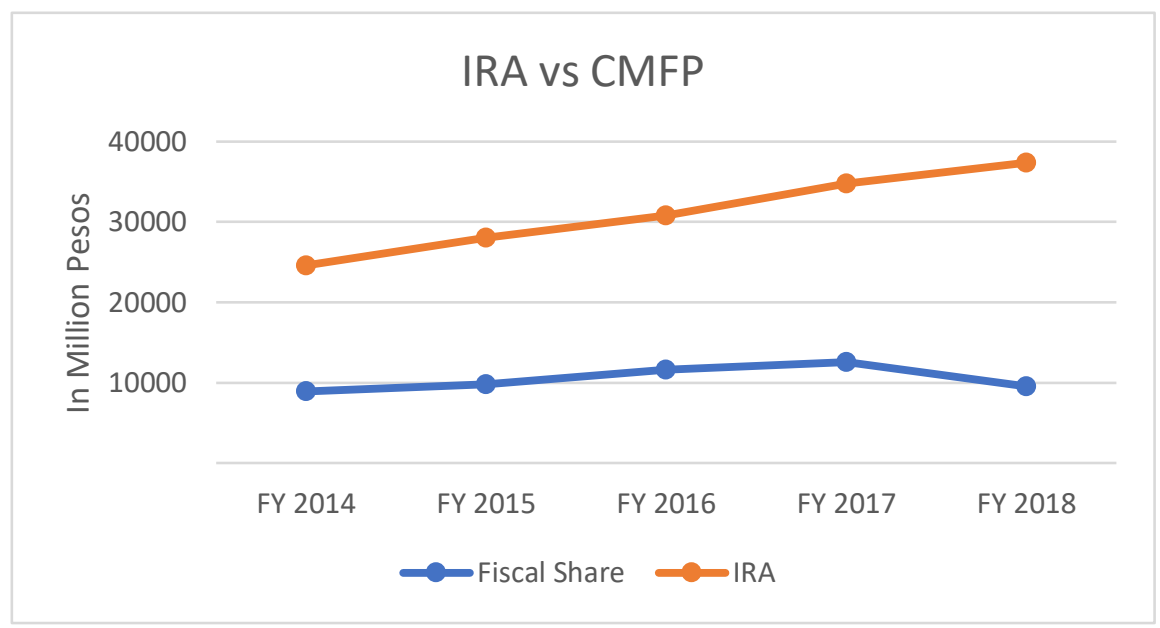

Figure 4. Graphical Representation of the Difference in the Internal Revenue Allotment and Fiscal Transfer to LGUs in the State of Northern Mindanao under CMFP Proposal for FY 2014 to FY 2018

Moving along as shown in Table 3, there is a decrease from the internal revenue allotment vis-à-vis the fiscal transfer to the LGUs in the CMFP proposal of $-64 \%$ in FY 2014 that is translated to a decrease of PHP 15,689 Million, at $-65 \%$ in FY 2015 that can be translated to a decrease of PHP 18,265 Million, at -62\% in FY 2015 which is translated to a decrease of PHP 19,225 Million, at -64\% in FY 2017 translated to PHP 22,258 Million, and 74\% decrease in FY 2018 which can be translated to a decrease of PHP 27,812 Million. 
As illustrated in Figure 4, the graph representing the fiscal transfer to the LGUs is lower than the graph of the internal revenue allotment.

Comparing the three federalism proposals presented in Tables 1 to 3 , the proposal of Pimentel will significantly (at the average of $85 \%$ ) increase the revenue of the LGUs in the State of Northern Mindanao as compared to Concom proposal which was at average of $18 \%$ only. On the contrary, CMFP proposal will even decrease the income of the LGUs by $66 \%$ at the average.

The increase in income of the LGUs under Pimentel proposal would translate to greater financial capacity to deliver basic services to the local communities in the State of Northern Mindanao.

\subsection{Proposed merging of Regions to one State}

Of the three proposals, Pimental and CMFP proposed for the merging of the current Northern Mindanao Region, Caraga Region, and Zamboanga Peninsula to be a part of the State of Northern Mindanao.

The Local Chief Executives have contradicting opinions over the proposed plan of merging. According to Mayor Calingasan, "Kaning second nga proposal (Pimentel and CMFP) dili gyud pabor sa LGU kay remember ang Caraga pobre gyud kaayo nga rehiyon. Kung i-merge sya madamay ang uban kay mao man magtapal aning Caraga labi na sa Surigao na side. [This second proposal (Pimentel and CMFP) is not favorable to the LGUs because remember that Caraga is a poor region. If it will merge (with Region X), the other LGUs will compensate the deficit of Caraga especially on the Surigao side.]

However, Mayor Moreno said, "I have no problem with that, upper half of Mindanao will be one region, one State. I have no problem with that. Do you know that Caraga used to be part of Northern Mindanao? And then Zamboanga Peninsula given its proximity to Northern Mindanao, it would not be difficult for us to be linked together. We are actually physically link together. The sharing of revenues, you know, I would not break my head on how is shared because the more important question is are the guys up there willing to give up power to raise revenues. That is the most important question. Let's not count the chicks before the eggs are hatched. So okay lang whatever it is okay lang. But then again the challenge is that, will power be given to the local level and the will revenues be allocated in favor of the local level.

\subsection{Fiscal decentralization and local autonomy}

Fiscal decentralization aimed to minimize the dependency of LGUs to the national government where local government units shall be relying in their local income to support the delivery of basic services to its constituents. The fiscal transfer in the form of internal revenue allotment (IRA) had been criticized for making the local government units to be dependent from the national support without maximizing the utilization of the local tax and revenue sources (Manasan, Philippine Journal of Development, 2005). It has been noted by the Bureau of Local Government Finance that the local government units remained as IRA dependent at $67 \%$ and local income contributed only 29\% (Bureau of Local Government Finance, 2017). 
Furthermore, Manasan (2007) mentioned that LGUs which received higher IRA tended to ease their efforts to implement local taxes and that there is a need to revisit the distribution formula of IRA to consider providing incentives for local tax efforts.

The proposal of Pimentel was an enhancement of the current fiscal transfer system in the form of the internal revenue allotment. It proposed that $80 \%$ of the tax collections will be distributed to the States and down to the LGUs instead of the $40 \%$ share of the LGUs in the tax collections. In the premise that current fiscal transfer system through IRA made LGUs dependent to the national support, increasing the share from $40 \%$ to $80 \%$ shall further increase the dependence of the LGUs to fiscal support from the National Government.

Table 4. Total Income of the LGUs of the State of Northern Mindanao under Pimentel Proposal for FY 2014 to FY2018

In Million Pesos

\begin{tabular}{lccccccc}
\hline Income Sources & FY 2014 & FY 2015 & FY 2016 & FY 2017 & FY 2018 & Average & Percentage \\
\hline Share from National Taxes & 59,118 & 66,723 & 72,305 & 83,337 & 87,932 & 73,883 & $88 \%$ \\
Share from State & 0 & 0 & 0 & 0 & 0 & 0 & $0 \%$ \\
Local Income & 7,661 & 8,851 & 9,724 & 10,927 & 11,807 & 9,794 & $12 \%$ \\
\hline Total Income & $\mathbf{6 6 , 7 7 9}$ & $\mathbf{7 5 , 5 7 3}$ & $\mathbf{8 2 , 0 2 8}$ & $\mathbf{9 4 , 2 6 4}$ & $\mathbf{9 9 , 7 3 9}$ & $\mathbf{8 3 , 6 7 7}$ & $\mathbf{1 0 0 \%}$ \\
\hline
\end{tabular}

As presented in Table 4, the fiscal transfer from the National Government comprised $88 \%$ of the total of the LGUs in the State of Northern Mindanao under Pimentel proposal. Comparing it with the finding of the BLGF in 2017 on IRA dependency of the LGUs of $67 \%$, the dependence of the LGUs if Pimentel proposal will be adopted will increase to $88 \%$.

On the other hand, based on the interview with key informants, it raises the question that, will the National Government willing to accept 80-20 sharing? According to Mayor Calingasan, Municipal Mayor of Libona, Bukinon, expressed doubts saying "Musugot pud kaha ang national government pud ana ba? Nga sila ang maningkamot, unya gamay ra ang ila. Unsa na lang mabilin sa ila? 20\%?" [Will the national government agree? That they will be the one to exert the efforts but too little left for them? What will remain for them? 20?]

Table 5. Total Income of the LGUs of the State of Northern Mindanao under ConCom Proposal for FY 2014-FY2018

In Million Pesos

\begin{tabular}{|c|c|c|c|c|c|c|c|}
\hline Income Sources & FY 2014 & FY 2015 & FY 2016 & FY 2017 & FY 2018 & Average & Percentage \\
\hline Share from State & 1,038 & 1,006 & 1,070 & 1,182 & 1,418 & 1,143 & $4 \%$ \\
\hline Local Income & 4,390 & 5,028 & 5,346 & 6,411 & 7,041 & 5,643 & $20 \%$ \\
\hline Total Income & 22,354 & 25,234 & 28,074 & 31,986 & 34,399 & 28,409 & $100 \%$ \\
\hline
\end{tabular}


On the other hand, the Concom proposal is the combination of the increase in national support from $40 \%$ to $50 \%$ but also strengthening the taxing power of the States by reallocating the identified taxes to the States.

As presented in Table 5, the share from the national taxes comprised $76 \%$ of the total income of the LGUs under ConCom Proposal while share from the state taxes is only $4 \%$ of the total income. In this case, ConCom proposal will not improve the dependence of the LGUs to National Government but rather will increase from $67 \%$ (Bureau of Local Government Finance, 2017) to $76 \%$.

Table 6. Total Income of the LGUs of the State of Northern Mindanao under CMFP Proposal for FY 2014-FY2018

In Million Pesos

\begin{tabular}{|c|c|c|c|c|c|c|c|}
\hline Income Sources & FY 2014 & FY 2015 & FY 2016 & FY 2017 & FY 2018 & Average & Percentage \\
\hline Share from National Taxes & 0 & 0 & 0 & 0 & 0 & 0 & $0 \%$ \\
\hline Share from State & 8,907 & 9,810 & 11,619 & 12,559 & 9,561 & 10,491 & $58 \%$ \\
\hline Local Income & 6,231 & 6,853 & 7,673 & 8,319 & 9,505 & 7,716 & $42 \%$ \\
\hline Total Income & 15,137 & 16,663 & 19,292 & 20,878 & 19,067 & 18,208 & $100 \%$ \\
\hline
\end{tabular}

Meanwhile, CMFP proposed to reassign tax collections to the States. The States will have the power to collect taxes that will be used for the delivery of basic services.

As shown in Table 6, the LGUs received 58\% of their income from the share of the state taxes and no income will come from the National Government. Furthermore, the local income percentage increased from $29 \%$ (Bureau of Local Government Finance, 2017) to $42 \%$.

Abueva (2005) pointed out that allocation of financial resources is of crucial importance in a federal set-up in order that the different levels of the government-Federal, State, and local governments will be able to their respective functions and to deliver basic services and developmental activities. However, the reassignment of the taxing power has its drawbacks. The local government will also incur additional cost of collection and compliance once the function to collect and raise revenue is decentralized.

According to Mayor Calingasan, “Ang government ani within the local manglihok gyud tanan, dili parehas sa amo karon ba relax-relax. Ang nagasakripisyo katong dagku nga lugar nga gahatag sa national. Unlike kun ingun ani federal, maningkamot gyud tanan. Pero mao lagi na, first five years lisod kaayo. Ang amo nakita five (5) years gyud, pag ka 6th year ana gwapo na. Murag ra ka ug naga-invest ana nga imong return of investment sa ika-6th year. (The government at the local level will all make efforts, unlike now that we are in slack. The one who exerts more efforts are those bigger LGUs that provides for the national government. Unlike if we are in a federal form, everyone will work hard. But indeed in the first five years it will be very hard. We foresee for the first five years, but in the sixth year it will be in place. It is just like investing that your return of investment will start on the sixth year)

However, Mayor Oscar Morena, City Mayor of Cagayan de Oro City expressed that, "actually the Abueva proposal is, I would say more liberal in that it empowers the state level to do whatever it wants and carve its 
owns destiny according to its own wishes, So I would say its up to the state level to come up with its own strategy. So it may sound most liberal and in fact in modern countries I would say that is more of the, that is now the more preferred system or division or structure. But then of course the bottomline man pud is the proof of the pudding is in the eating, in the end, the people will judge among the LGUs, among the states, where to live. So that's when the expression of voting with your feet would come into play. I want this state so I would go there. And I would go there because I prefer the way the state is doing its mandate. But the problem there is, you'll have a wider division between the successful states."

\subsection{Increasing the taxing power of the State}

As mandated in the Local Government Code, the cities were given broader taxing power over the municipalities and provinces (Bureau of Local Government Finance, 2015). As confirmed by Cagayan de Oro City Mayor Oscar Moreno, "cities especially the highly urbanized cities and including component cities are better off than municipalities and even provinces. Why? Because obviously the taxing power of the cities are far broader compared to the taxing powers of the municipalities and provinces. What the municipalities can do, the provinces cannot do. And what the provinces can do that the municipalities cannot do. So that provides the cities a distinct advantage, in terms of generating the revenues. And, if you are able to allocate the revenues judiciously, and deliver the services to your people, chances are your revenue potential would also increase. Why? Because more investments would come in, more businesses will be set up. And there would be more settlers who would come, so there will be improved land transactions, etc. etc."

Within this assumption, by increasing the taxing power of the local government unit or the State would mean greater opportunities to generate more revenues.

Out of the three federalism proposals, only Concom and CMFP proposals had considered to transfer the taxing power of National Government to the States.

The CMFP proposed to reallocate the taxing power to the States for major taxes such as income taxes on individuals and corporations as well as value-added tax. Moreover, CMPF proposed to transfer other percentages taxes such as franchise tax, taxes on banks and non-bank financial intermediaries, tax on finance companies, and tax on gross receipts of life insurance companies. The collection and levy of documentary stamp tax and taxes and fees under special laws were also proposed to be reallocated such as motor vehicle registration fees, private motor vehicle tax, travel tax, and charges on forest products (Citizens' Movement for a Federal Philippines (CMFP), 2005).

On the other hand, Concom proposed that the Federated Regions shall have the power to collect the real property tax, professional tax, franchise tax, and games and amusement tax. However, these taxes were already included in the revenue powers of the LGUs. Nevertheless, Concom also proposed to transfer the national taxes such as estate tax, donor's tax, documentary stamp tax to the Federated Regions as well taxes and fees under special laws such as environmental tax, pollution tax and similar taxes, road users tax, vehicle registration fees, transport franchise fees, and local taxes and other local taxes which may be granted by federal law (Consultative Committee to Review the 1987 Constitution, 2018). 
Table 7. Comparison of the List of National Tax Bases to be reallocated to the States under three (3) federal proposals

\begin{tabular}{|c|c|c|c|}
\hline National Tax Bases & ConCom & Pimentel & CMFP \\
\hline Income tax & & & $\square$ \\
\hline Value added tax & & & $\square$ \\
\hline Estate tax and Donor's Tax & $\square$ & & \\
\hline Franchise tax & $\nabla$ & & $\nabla$ \\
\hline Taxes on banks and non-bank financial intermediaries & & & $\nabla$ \\
\hline Tax on finance companies & & & $\square$ \\
\hline Tax on gross receipts of life insurance companies & & & $\square$ \\
\hline Documentary stamp tax & $\nabla$ & & $\nabla$ \\
\hline Motor vehicle registration fees & $\nabla$ & & $\nabla$ \\
\hline Private motor vehicle tax & $\square$ & & $\square$ \\
\hline Travel tax & & & $\square$ \\
\hline Charges on forest products & & & $\square$ \\
\hline
\end{tabular}

Comparing the three proposals as shown in Table 7, the CMFP proposal has given a greater advantage for the States to increase the power to generate more revenues with the broader taxing power. However, Mayor Moreno expressed that "I hope we can have a leadership at the national level and the leadership includes those who will be involved in the change process, who would be willing to give up power. That to me is the most important question. Who would be willing to give up power to someone else?"

He further expressed "But to me the formula as not as important as, one, the willingness of the national level to give power to the local level. And two, the willingness also of the national government to give power to the local level to generate more revenues. These are the two important questions."

\subsection{Spending priorities of the LGUs}

Based on 2018 National Budget, the national government allocated 37.8\% to Social Services, $30.6 \%$ for Economic Services, 21.8\% for General Public Services, and Debt Service 9.8\% (Department of Budget and Management, 2018) 
These allocation model should have been replicated at the local level. Department of Budget and Management Secretary Benjamin Diokno called on the local government units for not spending enough on social services. He said that the bulk of the local government funds were spent in local administrative functions instead of social services. It created the "unfavorable balance" as the country's population rises so must the spending on social services should also increase (Rey, 2017).

Based on the BLGF (2017) report, it was noted that the LGUs spent most of their budgets on general public services instead of social services.

Applying the 2018 national budget allocation to the 2018 total income of the LGUs derived from the three federalism proposals, the result is showed in the Table below.

Table 8. Allocation of 2018 LGU Income based on the 2018 National Budget under the Three Federalism Proposals

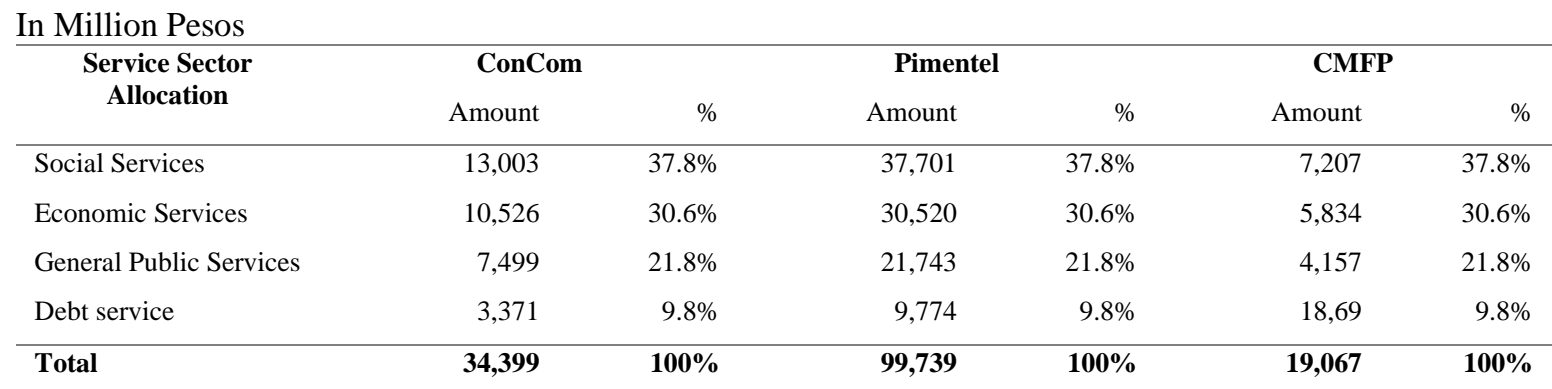

As presented in Table 8, the total income of the LGUs in the Northern Mindanao Federated Region in the FY 2018 under the Concom Proposal is PHP 34,399 Million. This amount is allocated to four service sectors namely, Social Services PHP 13,003 Million, Economic Services PHP 10,526 Million, General Public Services PHP 7,499 Million, and Debt Service PHP 3, 371Million.

Under Pimentel proposal, the LGU income in the FY 2018 is PHP 99,739 Million that will be allocated as follows; Social Services PHP 37,701, Economic Services PHP 30,520 Million, General Public Services PHP 21,740 Million, and Debt Service PHP 9,774 Million.

Furthermore, under CMFP proposal, the LGU income in the FY 2018 is PHP 19, 067 Million that will be allocated as follows; Social Services PHP 7,207 Million, Economic Services PHP 5,834 Million, General Public Services PHP 4,157 Million, and Debt Service PHP 1,869 Million. 


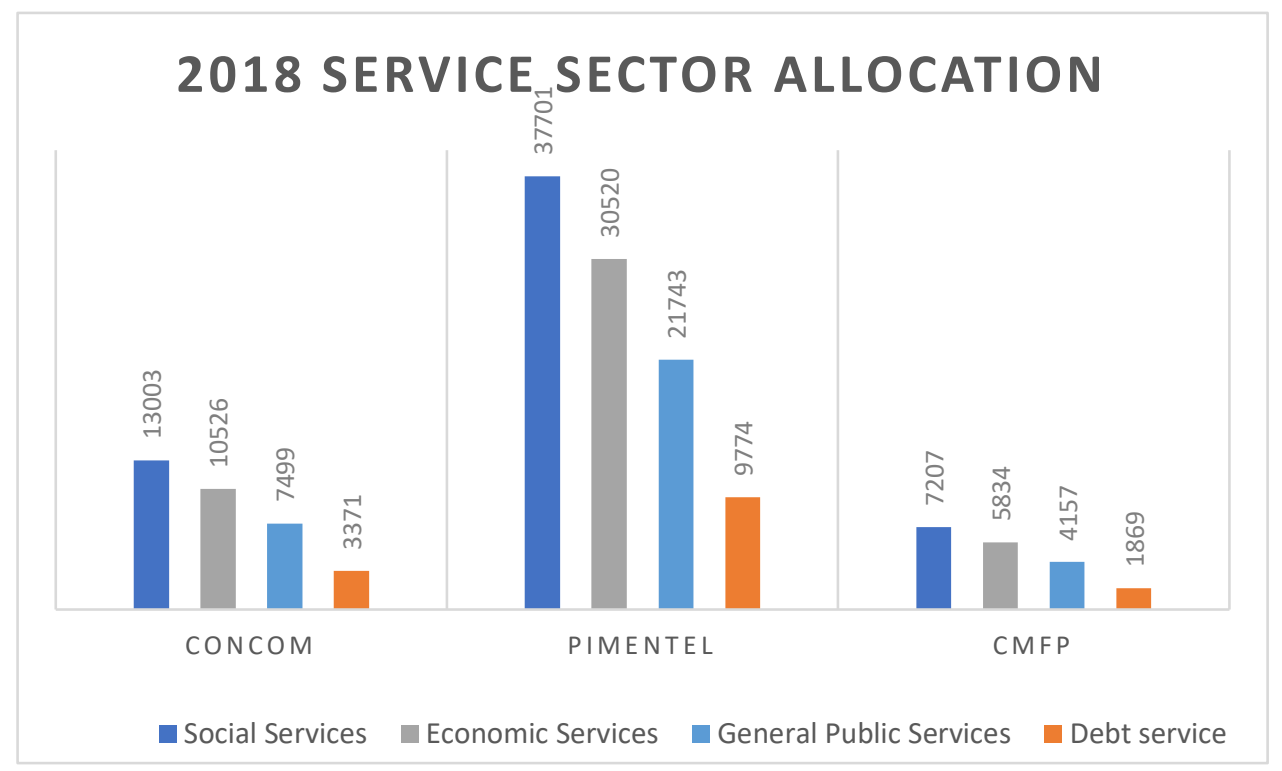

Figure 5. Graphical presentation of the 2018 Service Sector Allocation of LGU Income under the Three (3) Federalism Proposals

As shown in Figure 5, the graph represents the allocation of four service sectors in each federalism proposal. It was previously noted that the Pimentel proposal of 80-20 sharing will provide significant increase to the income of the LGUs. As showed in the graph, LGUs have greater capacity to provide for the delivery of basic services to the local communities under the Pimentel proposal.

In addition, in terms of money value, Pimentel proposal has the highest compared to the two other proposals. This means that under Pimentel proposal, the LGUs can allocate generous amount to fund their priority services and projects for their constituents.

In the real-life scenario presented in Table 9, however, the LGUs spent on the average of $28 \%$ only in social services in FY 2018. Almost half or even more than half of the budget of the provinces, cities, and municipalities were spent on general public services. 
Table 9. Actual Total Operating Expenditures of the Provinces, Cities, and Municipalities in FY 2018

In Million Pesos

\begin{tabular}{|c|c|c|c|c|c|c|c|c|}
\hline $\begin{array}{l}\text { Service Sector } \\
\text { Allocation }\end{array}$ & Provinces & $\%$ & Cities & $\%$ & Municipalities & $\%$ & Total & $\%$ \\
\hline General Public Services & $43,396.98$ & $44 \%$ & $86,395.64$ & $50 \%$ & $103,306.90$ & $64 \%$ & $233,099.52$ & $54 \%$ \\
\hline Social services & $31,508.24$ & $32 \%$ & $56,478.39$ & $33 \%$ & $31,317.10$ & $19 \%$ & $119,303.73$ & $28 \%$ \\
\hline Economic services & $21,580.11$ & $22 \%$ & $26,780.76$ & $16 \%$ & $25,316.61$ & $16 \%$ & $73,677.48$ & $17 \%$ \\
\hline Debt Service & $1,318.17$ & $1 \%$ & $1,572.73$ & $1 \%$ & $1,372.36$ & $1 \%$ & $4,263.27$ & $1 \%$ \\
\hline $\begin{array}{l}\text { Total Operating } \\
\text { Expenditures }\end{array}$ & 97,803.51 & $100 \%$ & 171,227.52 & $100 \%$ & $161,312.97$ & $100 \%$ & $430,344.00$ & $100 \%$ \\
\hline
\end{tabular}

Data Source: Statement of Receipts and Expenditures (SRE FY 2018 (Bureau of Local Government Finance, 2018)

As shown in the Table 9 above, the total operating expenditures of the Provinces in FY 2018 is PHP 97,805.51 Million wherein 32\% was spent in social services which amounted to PHP 31,508.24 Million, 22\% for economic services with equivalent amount of PHP 21,580.11 Million, the biggest chunk was spent for general public services at $44 \%$ that amounted to PHP 43,396.98 Million and lastly, $1 \%$ of the operating expenditure was allocated for Debt Service which amounted to PHP 1,318.17 Million.

The cities had the total operating expenditures of PHP 171,227.52 Million wherein 33\% was spent on social services which amounted to PHP 56,478.30 Million, 16\% on economic services in the amount of PHP 26,780.76 Million, 50\% was spent on general public services amounted to PHP 86,395.64 Million, and the remaining 1\% was allocated to Debt Service amounted to PHP 1,572.73 Million.

For municipalities, the total operating expenditures was PHP 161382.97 Million. This amount was broken down to $19 \%$ spent on social services amounting to PHP 31,317.10 Million, 16\% was spent on economic services amounted to PHP 25,316.61 Million, the largest share of 64\% was spent on general public services amounted to PHP 103,306.90 Million, and the remaining 1\% was spent on debt service amounting PHP 1,372.36 Million.

To test the allocation of the projected income of the municipality of Libona under the three proposals, the projected LGU income to be allocated to social, economic, general public, and debt services was compared to the actual operating expenditures in FY 2018. 


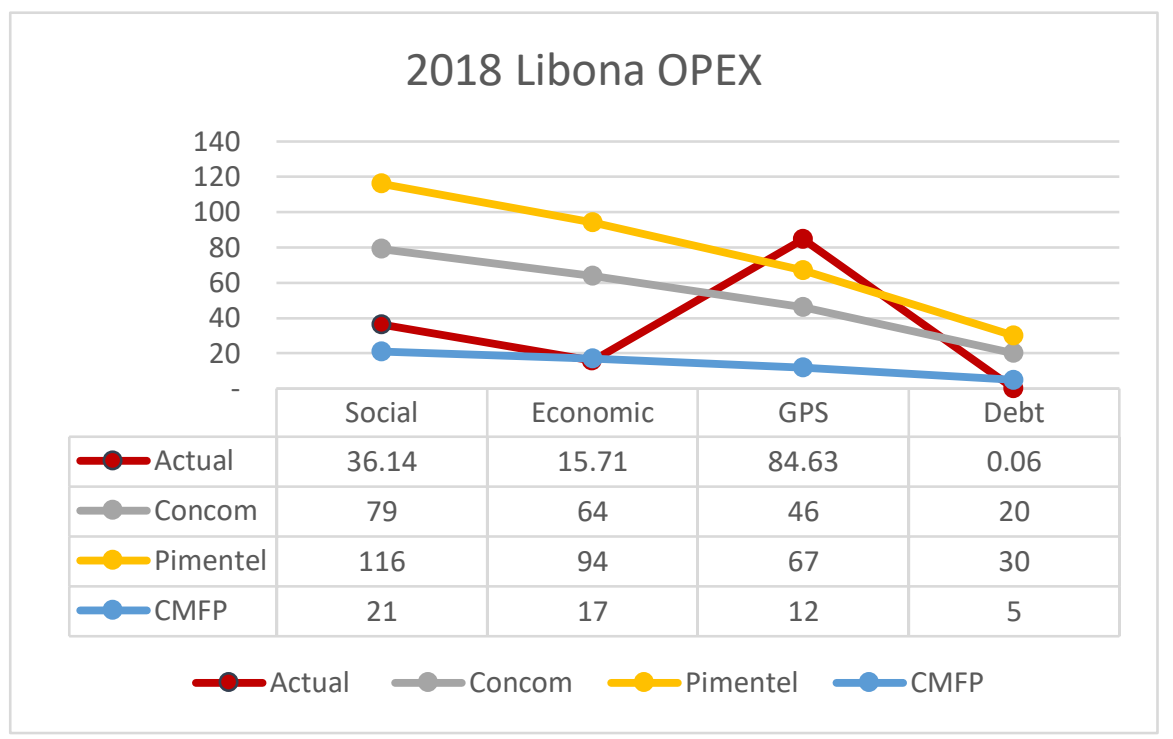

Figure 6. Graphical Representation of the Total Operating Expenditures of the Municipality of Libona as compared to the three federalism proposals in FY 2018

As illustrated in the graph in Figure 6, Libona spent the highest in the general public services amounting to PHP 84.63 Million while PHP 34.14 Million only for social services, PHP 15.71 Million on economic services, and PHP 0.06 Million on debt services (Bureau of Local Government Finance, 2018).

- Compared to the projected LGU Income to be allocated to the general public services under the three federalism proposals, the actual amount of general public services spending in FY 2018 was still the highest. It showed that even with the projected income of the LGU under the federalism proposals, the amount will be not enough to cover the general public services expenditure of Libona regardless of what proposal to implement.

Mayor Calingasan of Libona recognized that they have higher spending on general public services particularly the salaries of office personnel. It was due to mandatory positions that the LGU should comply with such as MDRR, office of the senior citizens, office of Gender and Development (GAD), youth development office, and the like. According to Mayor Calingasan, the local government should prioritize the economic activities to increase local income. "Ang local gyud unta ang $i$-focus ang maka strengthen sa economic activity. Kay income baya imong pangitaon. Mag invest gyud ka ug water system, pero ang number one gyud ang dalan gyud sya. Kay kung gwapo ang dalan, naa man gyud mu-invest." (The local level should focus on strengthening the economic activity. Because income is what you are aiming for. You invest in like water system, but the number one priority is the road system. If the road system is good, there will be investments coming in.)

He added "Kay kung mag federal na gani ka mag sige ra ka ug social services, mapurdoy gyud ka, mapurdoy gyud ang imo county. Pero mag-invest sa ka. Invest man gyud nimo to attact investor, sa makasulod dinhi after five years kanang imong investment makaluwas na nimo. Bisan asa ani nga sharing scheme nila, kailangan dapat ang mga munisipyo ang ila (i-focus mag invest), unlike sa ato karon sa atong present nagasalig ra ta IRA-national. Ang gwapo gyud iinvest, pareho sa ako karon in my last 3 years nag himo ko aning mga 
infrastructure nga kuan, asset lang siya pero non-income. Non-income asset ba. So akong ginapropose mga dalan, ipasemento. Kay chairman man sad ko sa infrastructure sa RDC, propose gyud ko nga masumpay na ang dalan paingon dinhi, karon nangasumpay na. Naka-timing pud nahimo pud ko nga chairman ba, pahimuslan ko ang higayon. So nagsulod na hinayhinay ang mga investor(s), naa nay ga-invest." [If we will go into federal form and you just focus on social services, your county will be at a losing end. But you should invest first. You will invest to attract investors to come in, after five years those investments will save you. Whatever sharing scheme, the municipalities (should focus on investing), unlike at the present that we are just dependent on IRA (internal revenue allotment) from the national government. The best move is to invest just like in my last three years (of my term), I created infrastructures that are just assets but non-income. Nonincome assets. So I proposed for road projects, concreating of roads. I am also a Chairman of the Infrastructure (Development Committee) in the RDC (Regional Development Council), so I proposed to continue the road system going here. Luckily, I became the chairman and have that opportunity. So the investors are slowly coming in, there are already those who invests.]

On the other hand, Mayor Moreno gave priority on the social services. "Not in our case, sa ato, we're heavy on health and education and these are social services. Health and education are very important."

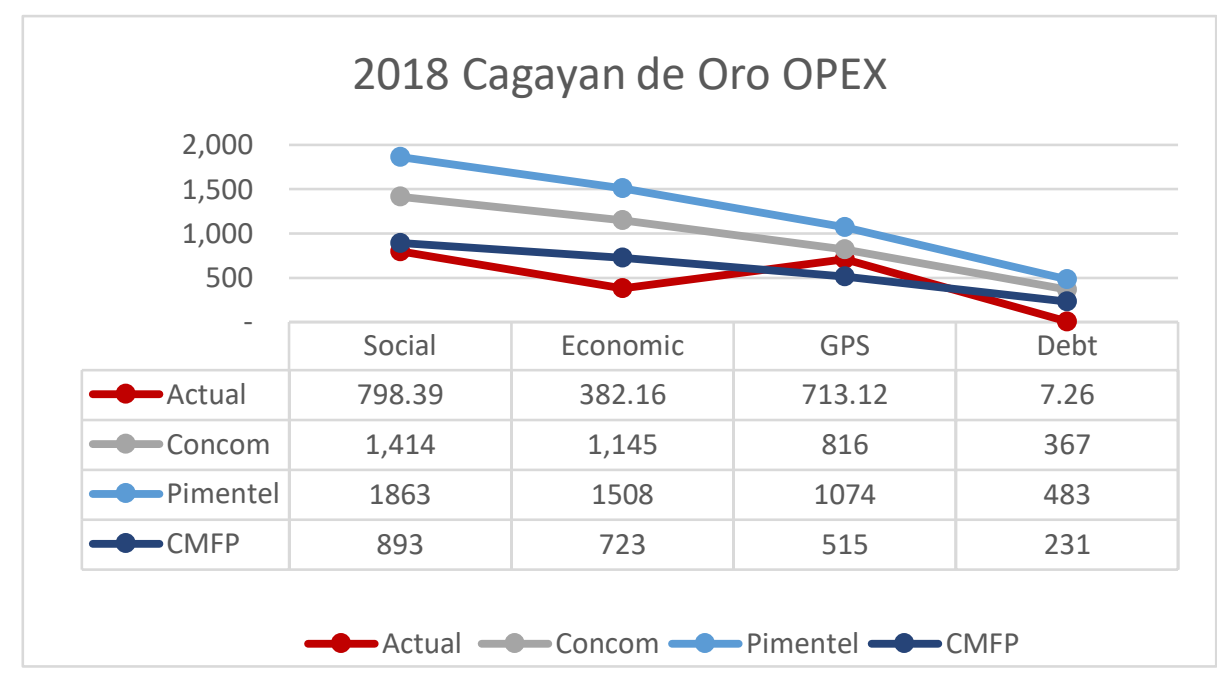

Figure 7. Graphical Representation of the Total Operating Expenditures of Cagayan de Oro City as compared to the three federalism proposals in FY 2018

As illustrated in Figure 7, the actual operating expenditures of Cagayan de Oro City was spent the highest in social services amounted to PHP 798.39 Million, followed by general public services which amounted to PHP 713.12 Million, economic services amounted to PHP 382.16 Million, and lastly PHP 7.26 Million on debt service (Bureau of Local Government Finance, 2018).

Given the actual spending of Cagayan de Oro City, Concom and Pimentel proposals are viable enough to cover its operating expenditures while CMFP proposal may not be enough to cover the general public services. 


\subsection{Perception of the Local Leaders on the proposal to shift to a federal form of government}

Based on the interview with the Key Informants, the higher share in the fiscal transfer to be received by the LGUs does not mean it is favorable for the LGUs. Mayor Gerardo Genesis T. Calingasan who was the Municipal Mayor of the Libona said "Mao na ang kahadlukan sa local nga perception sa LMP, sa League, mahadlok mi nga mawala. Politically, mahadlok ang mga politician, mawala man sila. Kay gamay man mi like Baungon. Sa among discussion didto, ang mga politiko magamay sila. Mabinlan lang ang daku nga clan. Ang proposal man gud nila mahimo ni nga States, magmerge man sila. So mawala na ni ang Baungon, mawala ang Sumilao. Gagmay man kaayo. Unsaon na na sila, baryo na lng na sila. Mahimo na lang na sila na county, manager na lang ibutang didto. So mawala si political lord didto sa Baungon. So ang dagku ang Manolo lang, so sila na lng ang magdumala sa ingon ani nga district. So ingon ana lugar ang among mga kahadluk...sa personal point of view sa mga politiko sa amo lokal, mao na ang mga nanggawas. [This is what the local chief executives feared of, the perception of the LMP (League of Municipalities of the Philippines), they will be abolished. Politically, the politicians are scared since they might be abolished. We are a small municipality like Baungon. In our discussion there, the number of politicians will become smaller. What will remain are the big clans. Their proposal was to convert into States, then there will be merging. So Baungon will be abolished, and so with Sumilao. They are very small (communities). What will happen to them, they will be turned into barrios. They will be turned into county, only a manager will be placed there. So the political lord of a municipality example Baungon will be abolished. So those bigger communities like Manolo (Fortich), they will be the one to lead the district. So that is what we feared of. On the personal point of view among us as local leaders, that was what emerged.]

Moreover. the local mayors in the League of Municipalities of the Philippines (LMP) also perceived that there will be a transition period of five (5) years when the Philippines will shift to a federal form of government. After the fiver year transition period, according to Mayor Calingasan, the local mayors anticipated that the National Government support will be pulled out and the LGUs and the States will be operating on their own. "Although gwapo ang federal after five (5) years kuno. Pero kanang transition period, mangita pa ka ug kwarta. May mga State nga kampante sila, sapian sila daan. Nagdugang pa ilang income di ba, tong wala nagasalig sa IRA. Pero kaning nagasalig sa IRA, unsaon? Unsaon na namo nga kanang,.makuha na namo, ma-achieve na namo nga income. So most likely ang Libona magamay guyd syag income. Sa pagkakaron kampante mi, daku na man income, daku na man gihatag sa IRA. Plus naga income mi hinayhinay nga hangtud nga naga daku man." [Although the federal form of government is good after five (5) years, but during the transition period, you still have to look for money. There are States that they are at ease since they have money. And their income is even increasing, for those not dependent on IRA. But for those that are just dependent to IRA? How can we achieve our income? So most likely Libona will have a decrease in income. For now, we are comfortable with the big income because we are receiving a big share of IRA. Plus, we are also earning slowly until we will earn much.]

He also mentioned the possible advantage of the Mandanas ruling to the LGUs that might make the shift to a federal government not feasible for now. He said, "kung magshift ta ug federal basta kung karon gwapo na unta ang collection system, income-revenue ba. Pro sa pagka karon, sa akong panglantaw, murag di pa gid angay karon. Di pa gid angay karon kay nakadaug pa gyud ang LGU sa IRA, (Mandanas petition), case sa IRA. Sa amo lang dinhi, 320 Million kolektahon sa national. Sa ako dinhi, ang ilang kuan dinhi, 30 Milion per year baya additional sa munisipyo." [If we will shift to federal as long as the collection system is already in place for income or revenue. But for now, the way I see it, it not yet timely. It is not yet timely especially that that the Local Government Units has won the case on IRA (Mandanas petition). For us here, we will collect 
PHP 320 Million from the national government. Here at my municipality, there will be PHP 30 Million due as additional income.]

On the other hand, Mayor Moreno emphasized that the move to shift to a federal form government is a complex process. He stated that, "We are now talking about the proposed federalization. You know, I would say that it's always good to discuss the mechanic or the various alternatives, but you know to me the biggest question is do we have enough leaders who can shepherd the march towards greater, towards federalization effectively. How many Cory Aquinos and Nene Pimentels do we have, and that to me is the biggest challenge. You can talk about the various alternatives, sharing between the states and federal government. And all of these to me are not bad, it's just a matter of determining which one is better unta. But none is bad. But the problem is how do we get to that. Do we have to have the-, do we have to the advocacy, do we have to have the people who would carry the flag. And of course, that would require, and then of course the process will be very important. Of course, you talk of state and federal sharing, that would require amendment of the constitution. And to do that, there are many issues that can be also be at least equally controversial or so much so that its hard to imagine, how can we move forward."

Furthermore, the local leaders recognized that Local Government Code has already given enough mechanism for the LGUs to operate independently. Mayor Calingasan expressed that "Gusto lang nila kanang independent, separate lang ang powers puro kun tan-awon nimo sa Local Government Code, full autonomy na man lang ang atong gapangayuon. Murag federal na man gud ta." (They just want independence, only separate powers but if you look at the Local Government Code, we are only looking for full autonomy. We are like in the federal setup already.)

Moreover, Mayor Moreno said "We can dream, we want to have a federalist system that's good, but failing that, what can you do, what can you do? Because we have to also address, no, what can we do in a given time, assuming that we don't have that yet. What can we do to be able to achieve the ends that we want to achieve with the federal system of government? I think the Local Government Code already gives us some advantage. I think, the important thing there is the LGU generates the revenue seriously and judiciously, and the revenues generated are allocated for public services judiciously as well. And then so you have the budget process, the implementation process and so on and everything is onboard. It can be done."

He further said that "Nene Pimentel became very unpopular after the local govt code took effect. He became unpopular especially among those national employees who were devolved to the local level. They were dislocated. People did not realize that local government code was actually empowering the local level. What the people thought was at that time was relegated the local government to the worse situation."

Table 10. Comparison of the three federal proposals vs the Internal Revenue Allotment received by the Municipality of Libona for FY 2014 to 2018

In Million Pesos

\begin{tabular}{lccccccc}
\hline & FY 2014 & FY2015 & FY2016 & FY 2017 & FY 2018 & Average & \% \\
\hline IRA & 98 & 112 & 123 & 141 & 151 & 125 & $100 \%$ \\
Concom & 125 & 140 & 158 & 179 & 192 & 159 & $127 \%$ \\
Pimentel & 191 & 215 & 233 & 261 & 288 & 238 & $190 \%$ \\
CMFP & 34 & 38 & 45 & 50 & 38 & 41 & $33 \%$ \\
\hline
\end{tabular}




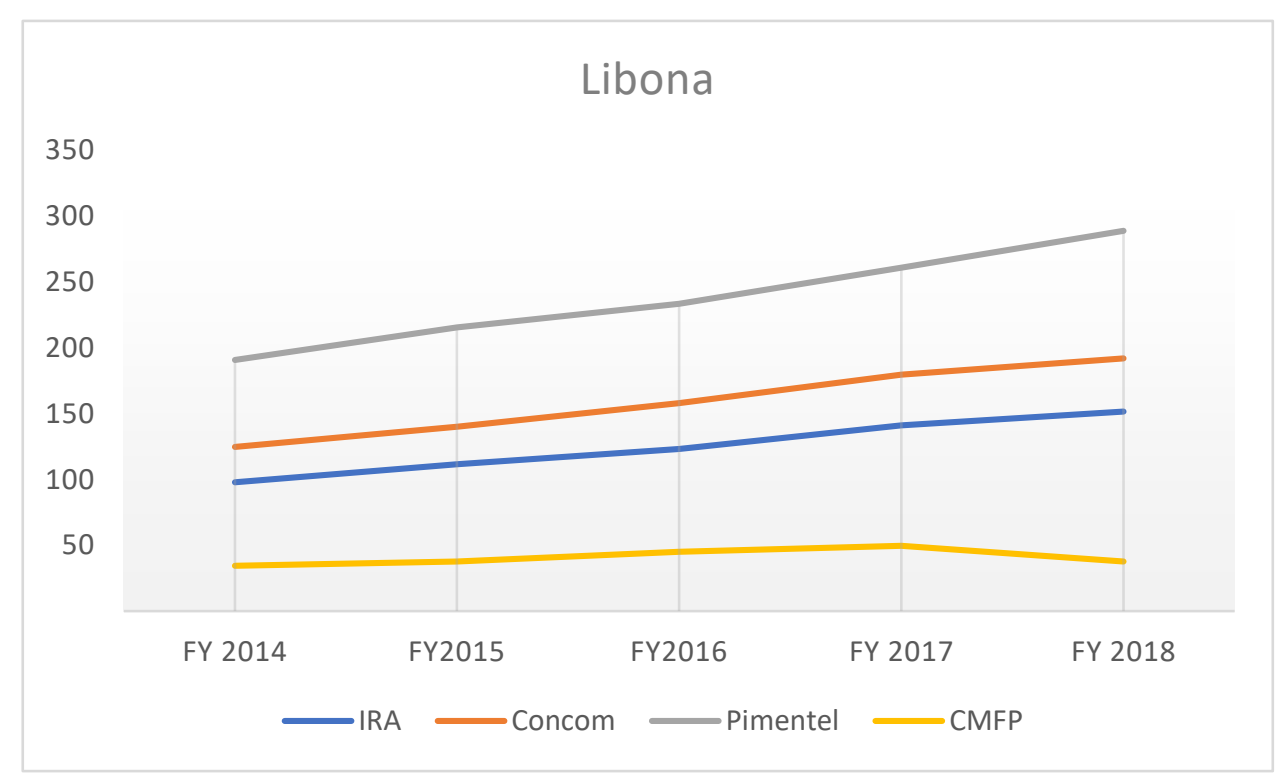

Figure 8. Graphical comparison of the three federal proposals against the Internal Revenue Allotment received by Libona for FY 2014 to 2018

As shown in Table 10, given the internal revenue allotment (IRA) at 100\%, there will be an average increase of $27 \%$ in the revenue of the Municipality of Libona under Concom proposal. Meanwhile, there will be a $90 \%$ increment under Pimentel proposal. However, CMFP proposal will decrease the revenue of Libona at 33\%.

Illustrated in Figure 8, the lines representing Pimentel proposal and ConCom proposal are located above the IRA line. However, the line representing the CMFP proposal is below the IRA line. This means that the Municipality of Libona will increase their revenue coming from the fiscal transfer to be received from the national government if either Pimentel or ConCom proposal will be adopted. Meanwhile, if CMFP proposal will be adopted, their revenue will decrease equivalent only to $33 \%$ of the current IRA.

In considering as to what is the best option that is favorable for the LGUs, Mayor Calingasan said, "So gwapo gyud gihapon tong 50-50\% sharing sa Concom kay kuhaon man tong tanan na states. As is man, say, di na mag increase ug tax nga makolekta kay naanad na man tawo ra mabayran kaning karon, strict lang gihapon ang pag collect sa tax so at least naa ka $27 \%$ bisag dili kaayo daku ang imong ma-increase pero assured ta. [The 50-50\% (Concom) sharing is still good because all States will receive. As it is, say, the tax collection will not increase since the people are already used to the same rate but there will be strict collection of taxes so at least I will have $27 \%$ (increase) not so much of an increase but assured already.] 
Table 11. Comparison of the three federal proposals vs the Internal Revenue Allotment received by Cagayan de Oro City for FY 2-014 to 2018

\begin{tabular}{lrrrrrrr}
\multicolumn{1}{l}{ In Million Pesos } & FY 2014 & FY 2015 & FY 2016 & FY 2017 & FY 2018 & Average & $\%$ \\
\hline IRA & 979 & 1119 & 1224 & 1408 & 1512 & 1248 & $100 \%$ \\
Concom & 1200 & 1350 & 1519 & 1747 & 1868 & 1537 & $123 \%$ \\
Pimentel & 1998 & 2255 & 2443 & 2894 & 3054 & 2529 & $203 \%$ \\
CMFP & 442 & 487 & 576 & 642 & 489 & 527 & $42 \%$ \\
\hline
\end{tabular}

Meanwhile for Cagayan de Oro City, Table 11 showed that there will a $23 \%$ increase in the revenue of Cagayan de Oro City if the Concom proposal will be adopted and 103\% increment under Pimentel proposal. However, there will a dropped to $42 \%$ if CMFP will be adopted.

To illustrate further in Figure 9 below, the line that represents Pimentel proposal is way higher from the IRA line. For Concom proposal, the line is also higher than IRA line but not as much as Pimentel's. However, for CMFP proposal, it is way below the IRA line which means that the revenue to be received by Cagayan de Oro City is lower than the internal revenue allotment it received from the National Government.

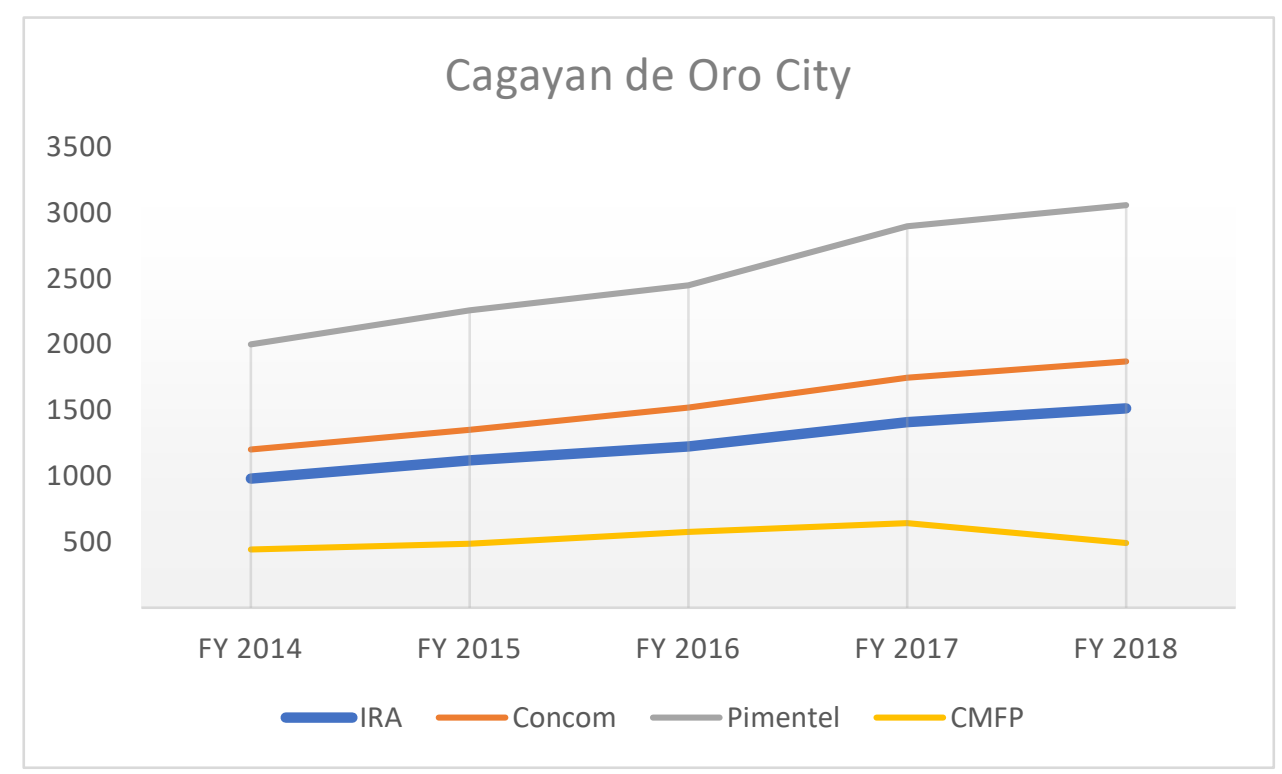

Figure 9. Graphical comparison of the three federal proposals against the Internal Revenue Allotment received by Cagayan de Oro City for FY 2014 to 2018

On the other hand, Mayor Oscar Moreno disclosed that "But you know everybody knows the importance of decentralization, the importance of federalism, the importance of bringing the government of closer. But, you the know problem really is, bottomline, how can we come up with the mechanism where there is sharing of power, and the revenue generation. These are two most important things. How can you design something that 
is power is shared- the sharing between the national government and the local level. Then secondly, how can you design something that the revenue generated is also shared again between the national and the local level.

He further expressed that "The bottomline here is there is no perfect system. Whatever option that will finally emerge it will never be perfect. But it is much better than where we are now. Much better. And then the bigger challenge is how do we get there given, one, willingness to give up power and, two, willingness to share resources.

\section{Conclusion and Recommendations}

The result of the study showed that the revenue of the Local Government Units will increase if the design of the fiscal transfer system of either Concom proposal or the Pimentel proposal will be adopted. The increase in revenues will be translated to higher budget ceiling to finance the devolve functions that could address fiscal imbalance.

On the other hand, as CMFP proposed to reallocate the taxing power of the National Government to the local level, it will also provide greater opportunities for the LGUs to be more capable to raise more revenues.

To further validate the suppositions, the researchers recommend the following:

1. Based on the projected LGU Income of the three federalism proposals, in terms of money value, the Pimentel proposal will provide the highest income to LGUs. However, increasing fiscal support would mean increasing the dependence of LGUs on the national government particularly in the case of provinces and municipalities. It is best to expand revenue sources and intensify tax collection so that the LGUs will have higher revenue from local sources. One way to expand revenue sources is to invest in economic enterprise or invest in infrastructure projects that will eventually attract potential investors. This was already done by the municipality of Libona as confirmed by Mayor Calingasan. Thus, such endeavor can also be applied by other municipalities. Additionally, further study should also be conducted to explore the revenue potential of the respective LGUs as to natural resources, tourism areas, areas suitable for businesses, and the like so that local income can be increased and in turn will decrease the LGU dependence on national support.

2. With the implementation of Mandanas ruling (Executive Order No. 138, 2021) where the IRA is expected to increase due to the inclusion of other national taxes as a basis for IRA computation, further study should be conducted to compare the effect of Mandanas ruling with the federalism proposals after five (5) years starting from its effectivity date on June 1, 2021. Furthermore, an in-depth review of the Local Government Code specifically on revenue allocation system to all levels of LGUs; provinces, cities, municipalities, and barangays should be done to determine its relevance and consistency with the Mandanas ruling as well as to determine if there is a need to shift to a federal system of government.

3. To federal proponents to consider the organizational setup of government collection agencies mainly the BIR and the Bureau of Customs as to how the taxing power will be distributed between the federal government and state government. CMFP proposed to reassign the national tax bases of the federal 
government to the State government. However, currently, the BIR has a centralized collection system wherein the large taxpayers regardless of situs, remits their collection to the Large Taxpayers Division. Further study should be conducted to review how the national government can allocate the collections of large taxpayers to respective regions so that a reasonable estimate of the effect of major taxes on the Regions or States can be foreseen. Bureau of Customs has also a centralized recording of collection. It may not be feasible for customs duties to be reassigned to the State level because not all States have Bureau of Customs collection districts. Thus, only the States where there are Bureau of Customs collection districts will benefit from customs duties collection.

4. The shift to a federal form of government is a complex process as Mayor Moreno had said. There should be leaders who are competent and eager to lead the whole country towards the move to federalism. Should it be decided, giving away to transition is the best option. Abueva (2005) had mentioned the transition period of five years and further study should be conducted to incorporate the provision on the transition period.

\section{Acknowledgement}

The authors are thankful to the Local Chief Executives, Mayor Oscar S. Moreno of Cagayan de Oro City and Mayor Leonardo Genesis T. Calingasan of the Municipality of Libona, Bukidnon who shared their time to give their valuable insights on the proposed federalization of the Philippines.

The authors are also grateful to the identified government agencies and institutions for providing relevant and vital information and contributed in one way or another to make this study possible most especially to the Bureau of Internal Revenue Region No. 16, Bureau of Local Government Finance Region X, Bureau of the Treasury Region X, and the University of Science and Technology of Southern Philippines (USTP).

To the families, friends, and co-workers of the authors, their words of encouragement and moral support made this study possible to which the authors are grateful of.

\section{References}

Abueva, J. V. (2005). Charter Change for Good Governance: Towards a Federal Republic of the Philippines with a Parliamentary Government. Marikina City: Citizen's Movement for a Federal Philippines (CMFP) and KC Institute of Federal-Parliamentary Democracy, Center for Social Policy and Governance, Kalayaan College.

Bahl, R. (2000, April). Intergovernmental Tranfers in Developing and Transition Countries: Principles and Practice. Retrieved from World Bank:

http://www1.worldbank.org/publicsector/LearningProgram/Decentralization/ITFPrinciples.pdf

Bureau of Internal Revenue. (2014 - 2018). BIR Collection Statistics. Retrieved from Bureau of Internal Revenue: https://www.bir.gov.ph/index.php/transparency/bir-collection-statistics.html

Bureau of Local Government Finance. (2015). Statistics. Retrieved from Bureau of Local Government Finance: http://blgf.gov.ph/lgu-fiscal-data/

Bureau of Local Government Finance. (2017). Statistics. Retrieved from Bureau of Local Government 
Finance: http://blgf.gov.ph/wp-content/uploads/2017/10/Consolidated-LGU-Financial-Performance1.pdf

Bureau of Local Government Finance. (2018). Statistics. Retrieved from Bureau of Local Government Finance: https://blgf.gov.ph/lgu-fiscal-data/

Bureau of the Treasury. (2018, July 11). Statistical Data. Retrieved from Bureau of the Treasury: https://www.treasury.gov.ph/

Citizens' Movement for a Federal Philippines (CMFP). (2005, February 14). Retrieved from Konrad Adenauer Stiftung: http://www.kas.de/wf/doc/kas_6315-544-2-30.pdf

Congressman Hermilando I. Mandanas, et al. Vs. Executive Secretary Paquito N. Ochoa, Jr., et al./Honorable Enrique T. Garcia, Jr. Vs. Honorable Paquito N. Ochoa, Jr., et al., G.R. No. 199802/G.R. No. 208488. April 10, 2019 (Supreme Court April 10, 2019).

Consultative Committee to Review the 1987 Constitution. (2018, July 16). Retrieved from Institute for Autonomy and Governance: http://iag.org.ph/index.php/blog/1587-full-document-consultativecommittee-s-draft-federal-constitution

Department of Budget and Management. (2018). Budget Documents. Retrieved from Department of Budget and Management: https://www.dbm.gov.ph/wpcontent/uploads/Our\%20Budget/2018/2018\%20QUICK\%20GLANCE\%2012202017.pdf

Department of Budget and Mangement. (2014 - 2018). Local Budget Memorandums. Retrieved from Department of Budget and Management: https://www.dbm.gov.ph/index.php/issuances/dbmissuances/local-budget-memorandum

Executive Order No. 138. (2021, June 1). Executive Order No. 138, s. 2021. Retrieved from Official Gazette of the Republic of the Philippines: https://www.officialgazette.gov.ph/2021/06/01/executive-orderno-138-s-2021/

Forest Management Bureau. (2014 - 2018). Philippine Forestry Statistics. Retrieved from Forest Management Bureau: https://forestry.denr.gov.ph/index.php/statistics/philippines-forestry-statistics

Land Transportation Office. (2014 - 2018). Annual Reports. Retrieved from Land Transportation Office: https://lto.gov.ph/transparency-seal/annual-reports.html

Manasan, R. G. (2005). Philippine Journal of Development. Retrieved from Philippine Institute of Development Studies: https://dirp4.pids.gov.ph/ris/pjd/pidspjd05-2publicfinance.pdf

Manasan, R. G. (2007, December). Policy Notes. Retrieved from Philippine Institute of Development Studies: https://dirp4.pids.gov.ph/ris/pn/pidspn0709.pdf

National Economic Development Authority - Region X. (2014 - 2018). Economic Updates. Retrieved from National Economic Development Authority - Region X: https://nro10.neda.gov.ph/all-qres/

Pimentel, A. J. (2008). Federalizing the Philippines: A Primer. Manila: Philippine Normal University Press.

Pimentel, A. J., Angara, E., Biazon, R., Cayetano, P., Enrile, J. P., Escudero, F., . . Villar, M. (2008, April 28). Legislative Documents. Retrieved from Senate of the Philippines: http://www.senate.gov.ph/

Republic Act No. 7160. (1991, October 10). AN ACT PROVIDING FOR A LOCAL GOVERNMENT CODE OF 1991. Retrieved from Official Gazette of the Republic of the Philippines: https://www.officialgazette.gov.ph/downloads/1991/10oct/19911010-RA-7160-CCA.pdf

Republic Act No. 9355. (2006, July 24). Republic Acts. Retrieved from Senate of the Philippines: http://legacy.senate.gov.ph/lis/pdf_sys.aspx?congress=13\&type=republic_act\&p=1

Rey, A. (2017, March 21). Local governments not spending enough on social services - budget chief. Philippines.

Shah, A., Boadway, R., Spahn, P., Hagen, J., Vigneault, M., Satoi, M., . . PETCH. (2006). INTERGOVERNMENTAL FISCAL TRANSFERS PRINCIPLES AND PRACTICE. Washington, DC, USA. Retrieved from ResearchGate: https://www.researchgate.net/publication/268523862_INTERGOVERNMENTAL_FISCAL_TRAN SFERS_PRINCIPLES_AND_PRACTICE 
Tourism Infrastucture and Enterprise Zone Authority. (2014 - 2018). Browse Request. Retrieved from eFOIElectronic Freedom of Information: https://www.foi.gov.ph/ 